\title{
Spondias mombin L. decoction utilization as antiseptic in cats submitted to castration
}

\section{Uso de decocto de Spondias mombin L. como antisséptico em felinos submetidos à castração}

\author{
Thalles D’avila Pires Dutra Dantas ${ }^{1}$; Francisco Marlon Carneiro Feijó ${ }^{1}$; Nilza Dutra Alves ${ }^{1}$; \\ Gardênia Silvana de Oliveira Rodrigues ${ }^{1}$ (D); Caio Sérgio dos Santos ${ }^{1}$; Waleska Nayane Costa Soares ${ }^{1}$; \\ Paula Vivian Feitosa dos Santos ${ }^{1}$; Letícia Cely Vieira de Medeiros ${ }^{1}$ \\ ${ }^{1}$ Universidade Federal Rural do Semi-Árido, Departamento de Ciências Agronômicas e Florestais, Rio Grande do Norte - RN, Brazil
}

\begin{abstract}
This survey evaluated mombin leaves (Spondias mombin L.) decoction efficiency as an antiseptic during post-surgery period on cats submitted to orchiectomy and ovariosalpingohisterectomy. For this purpose, 45 castrated mongrels cats were divided into three groups, the first group as a positive control using $0.5 \%$ chlorhexidine-alcohol solution, the second a negative control group using sterile distilled water and, finally, the test group using mombin leaves decocted with a concentration of $100 \mathrm{mg} / \mathrm{mL}$. All animals, independent of age and sex, had visibly healed in most cases in a similar time. Animals treated with mombin leaves decoction presented a significant reduction of bacterial growth. In addition, the animals treated in the test group had better surgical wound healing. All isolated bacterial strains presented inhibition halo for chlorhexidine and for Spondias mombin L. Thus, the decoction of Spondias mombin L. leaves proved antiseptic efficacy in the surgical wounds of cats submitted to orchiectomy and ovariosalpingohisterectomy.
\end{abstract}

Keywords: Medicinal plants. Orchiectomy. Ovariosalpingohisterectomy. Antimicrobial.

\section{RESUMO}

Foi avaliada a eficiência do decocto das folhas de cajá (Spondias mombin L.) como antisséptico no pós-cirúrgico de gatos submetidos à orquiectomia e ovariosalpingohisterectomia. Para tal, foram submetidos à castração 45 gatos sem raça definida, divididos em três grupos. O primeiro grupo como controle positivo com Solução Alcoólica de Clorexidine a 0,5\%; segundo grupo controle negativo com água destilada estéril; e o grupo teste com o decocto de cajá à concentração de $100 \mathrm{mg} / \mathrm{mL}$. Todos os animais, independentemente da idade e sexo, tiveram cicatrização visível em tempo similar. Animais tratados com o decocto apresentaram uma redução significativa do crescimento bacteriano. Além disso, observou-se uma melhor cicatrização das feridas cirúrgicas dos animais tratados no grupo teste. Todas as estirpes bacterianas isoladas apresentaram halo de inibição para clorexidine e para Spondias mombin L. Portanto, o decocto das folhas da Spondias mombin L. apresentou eficácia antisséptica nas feridas cirúrgicas de gatos submetidos à orquiectomia e ovariosalpingohisterectomia.

Palavras-chave: Plantas medicinais. Orquiectomia. Ovariosalpingohisterectomia. Antimicrobiano..

Correspondence to:

Gardênia Silvana de Oliveira Rodrigues

Universidade Federal Rural do Semi-Árido, Departamento de

Ciências Agronômicas e Florestais

Av. Francisco Mota, 572, Bairro Costa e Silva

CEP: 59625-900, Rio Grande do Norte - RN, Brazil

e-mail:gardeniavg@yahoo.com.br

Received: September 10, 2019

Approved: April 17, 2020
How to cite: Dantas TDPD, Feijó FMC, Alves ND, Rodrigues GSO, Santos CS, Soares WNC, Santos PVF, Medeiros LCV. Spondias mombin L. decoction utilization as antiseptic in cats submitted to castration. Braz J Vet Res Anim Sci. 2020;57(2):e162109. https://doi.org/10.11606/issn.16784456.bjvras.2020.162109

\section{Introduction}

Brazil is internationally recognized as having the largest biodiversity of plants on the planet (Soares et al., 2013; Sousa et al., 2018). The vegetation from the Caatinga biome, due to its multiplicity of use, shows economic potential related to animal feed, plant components utilization, wood production, and natural medicine (Silva et al., 2007; Sousa et al., 2018). Medicinal use of this potential has been highlighted by the scientific milieu (Soares et al., 2013). 
Phytotherapeutic medicinal products are pharmaceutical preparations (syrup, elixir, dye, fluid and dry extracts, ointments, cream, gel, pills, and capsules) characterized by a wide knowledge of their effectiveness, risks of their use and constancy of their quality to treat various diseases (Dias et al., 2017).

The use of these medicinal natural origin products has emerged as an alternative and is mainly due to the great search for phytotherapeutic remedies, linked to socioeconomic factors, maintenance of cultural traditions, availability to the population and the search for drugs with fewer side effects. In addition, it is also due to the inefficiency of some synthetic products and the high cost of allopathic medicines (Magalhães et al., 2015; Matias et al., 2010).

Mombin fruit (Spondias mombin L.) that belongs to the Anacardiaceae family, is found in tropical regions of America, Asia, Africa, and Brazil, mainly in the northeast and north region of the country. The medicinal use of plants of the genus Spondias is carried out by several communities, as well several scientific works supporting its use, even for resistant bacteria. Plants belonging to this genus have a potential to synthesize molecules with bacterial activity in the infectious process (Sá et al., 2016; Silva et al., 2014; Soares et al., 2006).

In studies on healing activity and antimicrobial activity using medicinal plants, most authors suggest that tannins are responsible for the pharmacological action, because of their astringent property. Although the astringency of tannins has not been systematically studied, it is known that the antioxidant compounds positively influence wound repair (Martelli et al., 2018).

In addition, high bacterial resistance to antimicrobials concerns professionals in many areas, as it is a problem that affects the entire population, increases treatments costs, and causes a higher number of infection mortality, which becomes a challenge for clinical handling (Magalhães et al., 2015; Matias et al., 2010).

Surgical sterilization consists of the removal of male or female gonads, called orchiectomy and ovariosalpingohisterectomy, respectively. These are among the most common surgeries in small animal clinics, since they are simple surgeries, affordable and quick. Owners' main objective of this type of surgery is to avoid animals having unwanted pups, and this surgery is widely performed (Conceição et al., 2017).

This study aimed to evaluate efficiency of decoction based on mombin leaves (Spondias mombin L.) in vitro and in vivo as an antiseptic in the post-surgery period of cats submitted to orchiectomy and ovariosalpingohisterectomy, since it is a promising antimicrobial alternative, according to Leonez et al. (2018).

\section{Material and Methods}

The Spondias mombin L. decoct production and processing of collected samples were performed at the Laboratory of Veterinary Microbiology (LAMIV), while animal surgical sterilization procedures were performed at the Dix-huit Rosado Veterinary Hospital (HOVET), both located at the Federal Rural Semi-Arid University (UFERSA), in the municipality of Mossoró, Rio Grande do Norte - Brazil. This research was evaluated by the Committee on Ethics and Use of Animals (CEUA) of UFERSA, with consent $n^{\circ}$. 20/2018.

From March to May 2018, 45 non-defined breed cats (Felis catus) were randomly selected, their owners received information about the experiment and signed the consent form allowing the surgery. These animals were then transferred to the HOVET, where they were subsequently anesthetized and submitted to ovariosalpingohisterectomy in females and orchiectomy in males. Post-surgical follow-up occurred in sanitized cats for a period of seven days, reinforcing that the animals received daily ration and water ad libitum.

Spondias mombin $\mathrm{L}$. leaves were harvested in the morning from a specimen on the university campus, then packed in bags and taken to LAMIV for processing. We noted that an exsiccate of the collection was deposited in Herbarium Dárdaro de Andrade Lima with n ${ }^{\circ} .13953$.

After the collection, $100 \mathrm{~g}$ of leaves were weighed in analytical balance (Cauduro LTDA, Model number EK3350), crushed and placed in Erlenmeyer, adding $1000 \mathrm{~mL}$ of distilled water. Afterward, this solution was boiled for $10 \mathrm{~min}$. Finally, the solution with a concentration of $100 \mathrm{mg} / \mathrm{mL}$ was filtered and conditioned in amber sterile glass and kept refrigerated until use.

The sample was divided into three randomized groups, comprising 15 animals each. The first group served as positive control (chlorhexidine-alcohol solution $0.5 \%$ ), the second, negative control (sterile distilled water), and the third, the test group with mombin leaves decoction $100 \mathrm{mg} / \mathrm{mL}$. The animals were treated daily for seven days, with disinfection and collection of the samples performed daily at the surgical incision spot with the aid of sterile swab after $10 \mathrm{~min}$ of the antiseptic action.

Swab samples were collected in a tube containing $2 \mathrm{~mL}$ of sterile distilled water, and subjected to the dilutions $10^{1}, 10^{2}$ and $10^{3}$, respectively. After the procedure, $1 \mathrm{~mL}$ of each dilution was seeded in plate count agar and incubated in a bacteriological oven for $24 \mathrm{~h}$ at a temperature range of 
$37^{\circ} \mathrm{C}$ to $37.5^{\circ} \mathrm{C}$, the necessary time for bacterial counting by mesophilic present in each dilution (Tortora et al., 2017).

After isolating bacteria, they were cultured in BHI broth for $24 \mathrm{~h}$ at $37^{\circ} \mathrm{C}$ to $37.5^{\circ} \mathrm{C}$ until the log phase for approximately $18-24 \mathrm{~h}$, adjusted by the McFarland scale. Microorganisms were identified by cytology and biochemical tests (MacFaddin, 2000).

The standard inoculum of each microorganism was cultured for diffusion testing in Mueller-Hinton agar at the concentration of 0.5 of the McFarland scale for 18-24 h. The sensitivity test to extracts by agar diffusion was performed according to antimicrobial sensitivity test for diffusion-disc (National Committee for Clinical Laboratory Standards, 2003).

Microbiological analyses results were submitted to the analysis of variance and the means were compared to each other by the Scott-Knott test, at the 5\% probability level, using statistical software Sisvar ${ }^{\circledR}$.

\section{Results and Discussion}

Number of females was higher than number of males, in which a ratio of 1: 1.50 (male: female) was observed, adults number was higher than kittens number: 0.79 (adult: kitten). All animals, independent of age and sex, had visible healing at a similar time. Kiani et al. (2014), on the other hand, studied healing in cats submitted to ovariosalpingohisterectomy, in which they observed that adult cats during the post-surgery period formed greater granulation tissue and fibroblast maturation scores in their surgical wounds, as well as the formation of neovascularization and reepithelialization, when compared to young cats.
As observed in Figure 1, animals treated with sterile distilled water had the highest number of microorganisms found, since water has no ability to inhibit bacteria. However, animals treated with Spondias Mombin L. presented a significant reduction of bacterial growth.

Results with chlorhexidine at $0.5 \%$ were better than the negative control (sterile distilled water), since this antiseptic is characterized by being a cationic detergent of the biguanides class available in acetate, hydrochloride and digluconate forms. This last one is the most commonly used salt in formulas and products, which has a wide spectrum of action, acting on gram-positive, gram-negative bacteria, fungi, yeasts, and lipophilic viruses (Tortora et al., 2017). However, better healing of the surgical wounds of those treated with Spondia mombin L. was observed, with Castejon (2011), reporting that the healing activity can be attributed to tannins, stimulation of phagocytic cells, as well as anti-infective activities.

Regarding the bacteria found in the surgical wounds of cats treated with the negative control, Staphylococcus aureus, Staphylococcus hycus, Staphylococcus coagulase-negative, Corynebacterium sp. and Gram-positive bacilli strains, all bacterial strains isolated from the negative control were tested in vitro and presented inhibition halos for 0.5\% chlorhexidine and for the decoction of the mombin leaves (Figure 2).

Similar results were described by Leonez et al. (2018), when they found that the mombin leaves extract was effective on inhibiting coagulase-negative Staphylococcus ampicillin-resistant, isolated from goat teats, demonstrating the actual antimicrobial potential of compounds in the mombin plant.

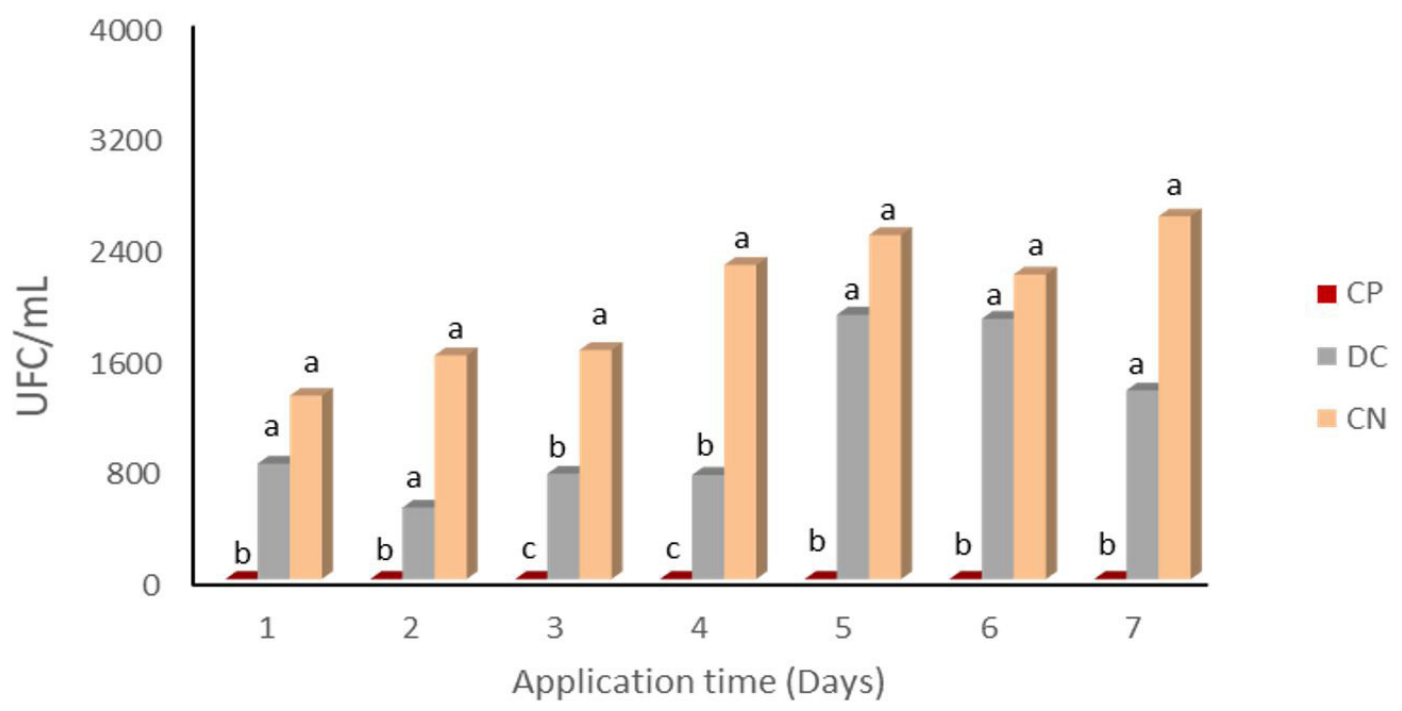

Figure 1 -Mongrel cats submitted to castration surgery. Bacterial count in the period of seven days after surgery. $\mathrm{CP}=$ positive control (chlorexidine-alcohol 0.5\%); DC = test group (Spondia monbin L decot); CN = Negative Control (sterile distilled water). Averages followed by the same letters do not present significant difference $(\mathrm{p} \geq 0.05)$ by the Scott-Knott test. Mossoró, Brazil, 2020. 


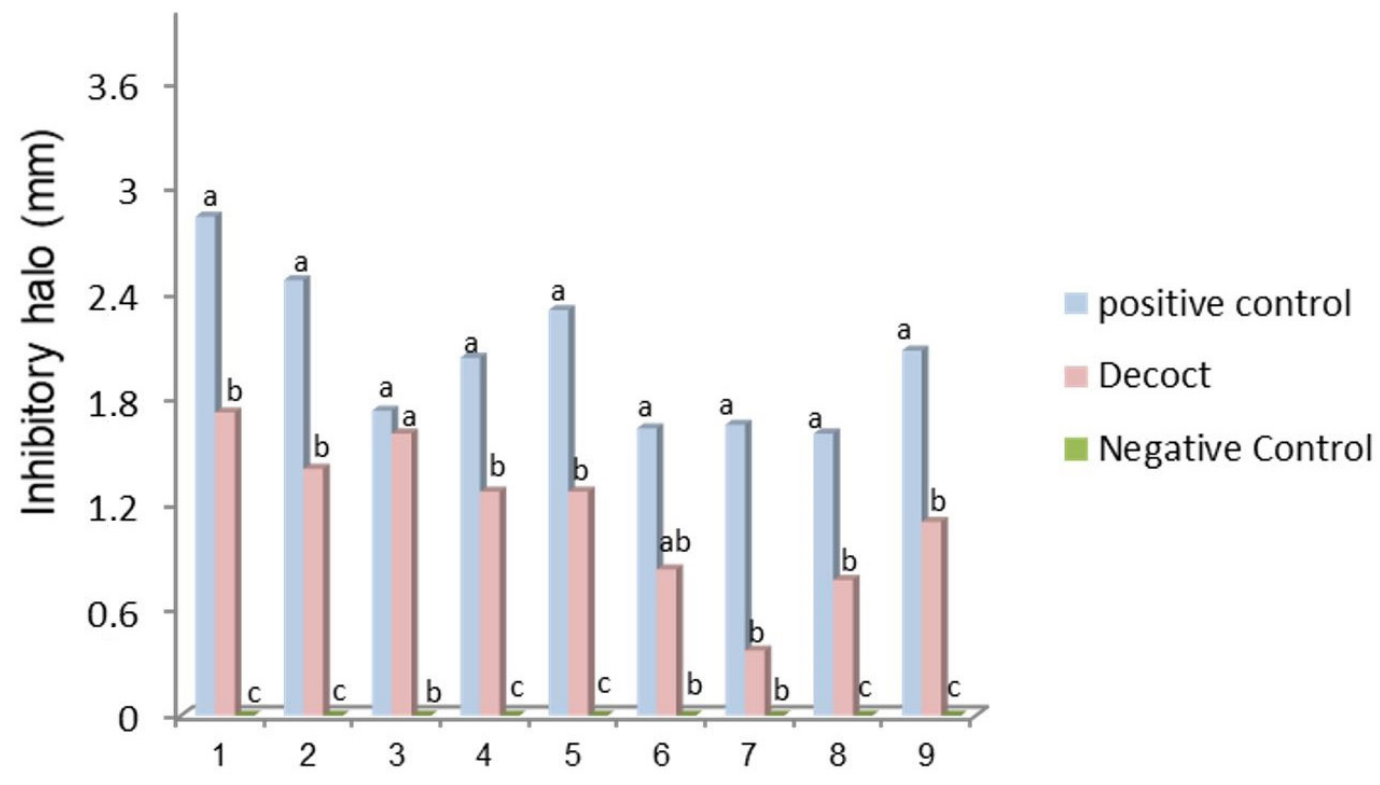

Figure 2 - Mongrel cats submitted to castration surgery. Inhibitory halo diameters formed after diffusion in well test for bacteria found in the negative control animals. The numbers in sequence represent: (1) Staphylococcus hyicus; (2) Staphylococcus -coagulase-negative strain 1; (3) Staphylococcus coagulase-negative strain 2; (4) Gram positive bacillus strain 1; (5) Corynebacterium sp. strain 1; (6) Corynebacterium sp. Strain 2; (7) Gram positive bacillus strain 2; (8) Staphylococcus-coagulase-negative strain 3; (9) Staphylococcus - coagulase-negative strain 4; Staphylococcus aureus. Positive Control (chlorhexidine-alcohol, 0.5\%); Negative Control (sterile distilled water); Test Group (Spondia monbin L decot). Mossoró, Brazil, 2020.

Table 1 - Mongrel cats submitted to castration surgery according to sex, experimental group, and evaluation of healing evolution after seven days of surgery. Mossoró, Brazil, 2020

\begin{tabular}{|c|c|c|c|c|c|c|}
\hline \multirow{2}{*}{ Variable } & \multicolumn{2}{|c|}{ Positive Control* } & \multicolumn{2}{|c|}{ Negative Control** } & \multicolumn{2}{|c|}{ Spondias mombin L. } \\
\hline & Male & Female & Male & Female & Male & Female \\
\hline Hyperemia & - & - & - & - & - & - \\
\hline Edema & - & - & - & - & - & - \\
\hline Secretion & - & - & - & 3 & - & - \\
\hline Crusts & - & - & - & - & - & - \\
\hline Dehiscence & - & - & - & - & - & - \\
\hline Without changes & 7 & 8 & 6 & 6 & 5 & 10 \\
\hline
\end{tabular}

*chlorhexidine-alcohol, $0.5 \%$. **sterile distilled water.

Regarding the clinical feature of the animals under study, we observed that the animals submitted to care with the decoction of Spondia mombin L., distilled water and chlorhexidine did not present significant differences regarding hyperemia, edema, secretion, crusting, and dehiscence, with the exception of the presence of secretion in $20 \%$ ( 3 females) of the negative control (Table 1).

These data were similar to the results found by França et al. (2008), when using ointment based on Symphitum oficcinalis (confrei) on surgical wounds of cats. This plant is popularly used for its healing and tissue regenerating properties, which confer healing and anti-inflammatory effects similar to the results found in the present study.

França et al. (2008), reported satisfactory results in almost $80 \%$ of the animals, presenting normal healing, but some with crust formation, due to the astringent action of the tannin. However, in the present study, none of the animals treated with Spondias mombin L. presented differences in the normal cicatricial process.

\section{Conclusion}

It can be concluded that Spondias mombin L. leaves decoction presents antiseptic efficacy in surgical wounds of cats submitted to orchiectomy and ovariosalpingohisterectomy, proving its use as an alternative technology to industrialized antimicrobials.

\section{Conflict of Interest}

We declare that we do not have conflicts of interest.

\section{Ethics Statement}

The study was approved by the Committee on Ethics and Use of Animals (CEUA - UFERSA) nº. 20/2018. 


\section{References}

Castejon FV. Taninos e saponinas [dissertação]. Goiânia: Curso de Ciência Animal, Universidade Federal de Goiás; 2011.

Conceição ASMM, Souza Neto JL, Freire RF, Costa PPC. Infecção pós-cirúrgica em felino: relato de caso. Rev Bras Hig Sanid Anim. 2017;11(2):198-215.

Dias ECM, Trevisan DD, Nagai SC, Ramos NA, Silva EM. Uso de fitoterápicos e potenciais riscos de interações medicamentosas: reflexões para prática segura. Rev Baiana Saúde Pública. 2017;41(2):297-307. http://dx.doi. org/10.22278/2318-2660.2017.v41.n2.a2306.

França ISX, Souza JA, Baptista RS, Britto VRS. Medicina popular: benefícios e malefícios das plantas medicinais. Rev Bras Enferm. 2008;61(2):201-8. http://dx.doi.org/10.1590/ S0034-71672008000200009.

Kiani FA, Kachiwal AB, Shah MG, Khan MS, Lochi GM, Manan A, Ul Haq I, Khan FM. Histological characterization of wound healing of flank verses midline ovariohysterectomy in different age groups of cats. Journal of Clinical Pathology and Forensic Medicine. 2014;5(2):6-16. http://dx.doi. org/10.5897/JCPFM2013.0048.

Leonez CF, Feijo FMC, Alves ND, Santos CS, Rodrigues GSO, Fernandes FC, Matos TM. Efficacy of the decoction of cashew leaf (Spondias mombin L.) as a natural antiseptic in dairy goat matrices. Afr J Agric Res. 2018;13(13):644-9. http://dx.doi.org/10.5897/AJAR2017.12751.

MacFaddin JF. Biochemical test for identification of medical bacteria. 3rd ed. Baltimore: Awolters Kluwer; 2000.

Magalhães LS, Pussente CG, Azevedo LR, Crespo JMRS. Avaliação da atividade antibacteriana do extrato de Caesalpinia ferrea Martius e desenvolvimento de uma formulação fitocosmética. Rev Cient Faminas [Internet]. 2015 [cited 2019 Jun 3];11:27-43. Available from: http://www.faminas. edu.br/upload/downloads/20150617214048_59335.pdf

Martelli A, Andrade TAM, Santos GMT. Perspectivas na utilização de fitoterápicos na cicatrização tecidual: revisão sistemática. Archives of Health Investigation. 2018;7(8):34450. http://dx.doi.org/10.21270/archi.v7i8.3047.

Matias EF, Santos KKA, Almeida TS, Costa JGM, Coutinho HDM. Atividade antibacteriana In vitro de Croton campestris A., Ocimum gratissimum L. e Cordia verbenacea DC. Rev
Bras Biocienc [Internet]. 2010 [cited 2019 Jun 2];8:294-8. Available from: http://www.ufrgs.br/seerbio/ojs/index.php/ $\mathrm{rbb} /$ article/view/1428.

National Committee for Clinical Laboratory Standards. NCCLS M2-A8: performance standards for antimicrobial disk susceptibility tests: approved standard. 8th ed. Wayne: NCCLS; 2003.

Sá PF Jr, Muniz EB, Pereira NA, Oliveira MAS. In vitro antimicrobial activity of aqueous extracts, hydroalcoholic and alcoholic species of Anacardiaceae family. Rev Ciênc Méd Biol [Internet]. 2016 [cited 2019 Jun 3];15:56-61. Available from: https://docs.ufpr.br/ pdalzoto/2016BIO009NOITE2EQ1.pdf.

Silva JG, Souza IA, Higino JS, Siqueira JP Junior, Pereira JV, Pereira MSV. Atividade antimicrobiana do extrato de Anacardium occidentale Linn.em amostras multiresistentes de Staphylococcus aureus. Rev. Bras. Farmacogn [Internet]. 2007 [cited 2019 Jun 3], 17(4):572-577. Available from: http://www.scielo.br/scielo.php?pid=S0102695X2007000400016\&script=sci_abstract\&tlng=pt.

Silva GA, Brito NJN, Santos ECG, Lópes JÁ, Almeida MG. Spondias genus: botanical aspects, chemical and pharmacological potential. Rev Biol Fram. 2014;10:1-16.

Soares EB, Gomes RLF, Carneiro JG, Nascimento FN, Silva ICV, Costa JCL. Caracterização física e química de frutos de cajazeira. Rev Bras Frutic. 2006;28(3):518-9. http://dx.doi. org/10.1590/S0100-29452006000300039.

Soares JA, Barros M, Gonçalez WP, Crisci AR, Jorge MHS. Avaliação da atividade cicatrizante da Caesalpinia férrea ex. TUL.var ferrea e da Aloe vera (L.) Burm. f. em lesões cutâneas totais em ratos. Perspect Online [Internet]. 2013 [cited 2019 Jun 3];3:33-42. Available from: http://www.seer. perspectivasonline.com.br/index.php/biologicas_e_saude.

Sousa IJO, Araújo S, Negreiros PS, França NRS, Rosa GS, Negreiros FS, Gonçalves RLG. A diversidade da flora brasileira no desenvolvimento de recursos de saúde. UNINGÁ Rev [Internet]. 2018 [cited 2019 Jun 2];31(1). Available from: http://revista.uninga.br/index.php/uningareviews/article/ view/2048.

Tortora GJ, Funke BR, Case CL. Microbiologia. 12a ed. Porto Alegre: Artmed; 2017.

Financial Support: PIBIT/CNPq. 